\title{
Is the use of intraoperative nerve monitoring an effective method to reduce the rate of permanent recurrent laryngeal nerve paralysis?
}

\author{
İntraoperatif sinir monitorizasyonu kalıcı rekürren laringeal sinir paralizi oranının azaltılmasında \\ etkili bir yöntem midir?
}

\author{
Doğan Yıldırım ' , Turgut Dönmez ${ }^{2}$, Mikail Çakır ${ }^{1}$, Okan Murat Aktürk ${ }^{1}$, Adnan Hut ${ }^{1}$, Ahmet Kocakuşak ${ }^{1}$, Erdinç \\ Çekiç ${ }^{3}$, Leyla Zeynep Tigrel ${ }^{1}$, Turgay Yıldız ${ }^{1}$
}

\section{Abstract}

Aim: Recurrent laryngeal nerve (RLN) paralysis is a common complication of thyroid surgery. In recent years, intraoperative nerve monitoring (IONM) has been used to reduce the risk of RLN paralysis. The purpose of this study was to assess the role of IONM in reducing RLN paralysis.

Methods: A retrospective clinical study was conducted between January 2015 and January 2017 in a two-centerclinical trial at Lutfiye Nuri Burat State and Haseki Teaching and Research Hospitals. Patients who underwent thyroidectomy using IONM (Group A, n=100) or direct visual technique (Group B, $n=232$ ) were included. Patients' files were reviewed for age, body mass index, gender, American Society of Anesthesiologists score, calcium levels, complications, duration of operation and follow-up. Postoperative complications were regarded as the main outcomes.

Results: A total of 332 patients ( 52 male, 280 female) with a mean age of $46.4 \pm 12.9$ years were enrolled. $30.1 \%$ of the patients were in Group A (IONM). Bilateral and unilateral thyroidectomies were performed in $70.8 \%$ and $29.2 \%$ of the operations, respectively. Operative time was shorter in Group A ( $76.9 \pm 12.0$ minutes vs $97.7 \pm 27.6$ minutes, $p$ <0.001). There was no significant difference between the two groups in terms of preoperative and postoperative calcium levels $(\mathrm{p}=0.407)$. There was no statistically significant difference in early RLN paralysis rates between the two groups (for Group A and Group B, $10(10 \%)$ and $34(14 \%)$, respectively) $(\mathrm{p}=0.251)$ While it was not present in Group A, permanent RLN paralysis was found in 10 patients in Group B (4.3\%) (p = 0.035).

Conclusion: The use of IONM may be useful in reducing the rate of permanent RLN paralysis.

Keywords: Thyroidectomy, Recurrent laryngeal, Nerve monitoring

\section{Öz}

Amaç: Rekürren laringeal sinir (RLN) paralizisi tiroid ameliyatının bilinen bir komplikasyonudur. RLN paralizisi riskini azaltmak için son yllarda intraoperative sinir monitorizasyonu (IONM) yöntem kullanılmaktadır. Bu çalışmanın amacı IONM kullanılmasının RLN paralizisinin azaltılmasındaki potansiyel rolünü değerlendirmektir.

Yöntemler: Ocak 2015-Ocak 2017 tarihleri arasında çift merkezli, retrospektif klinik bir çalışmada Lütfiye Nuri Burat Devlet Hastanesi ve Haseki Eğitim ve Araştırma hastanesinde yapılan troidektomi ameliyatları incelendi. Hastalar IONM kullanılarak yapılan troidektomi (Grup A, n=100) ve direkt görsel teknik kullanılarak yapılan troidektomi (Grup B, $\mathrm{n}=232$ ) olarak çalışmaya dahil edildi. Hastaların dosyaları incelenerek yaş, vücut kitle indeksi, cinsiyet, ASA skoru, kalsiyum seviyeleri, komplikasyonlar, ameliyat süreleri, takip süreleri incelendi. Postoperatif komplikasyonlar esas çıktı olarak belirlendi.

Bulgular: Çalışmaya tiroid operasyonu yapılan yaş ortalamaları 46,4 $\pm 12,9$ yıl olan 52 erkek, 280 kadın toplam 332 hasta dahil edildi. Hastaların \%30,1'i İNM kullanılan, \%69,9’u kullanılmayan grupta idi. Operasyonların $\% 70,8$ 'i çift taraflı, \%29,2'si tek taraflıydı. IONM grubunda ameliyat süreleri diğer gruptan daha kısa idi $(76,9 \pm 12,0$ dakika ve $97,7 \pm 27,6$ dakika, $\mathrm{p}<0.001)$. Preoperatif ve postoperatif kalsiyum seviyeleri açısından iki grup arasında anlamlı bir fark saptanmadı $(\mathrm{p}=0.407)$. İki grup arasında erken dönem RLN paralizisi oranlarında istatistiksel olarak anlamlı fark saptanmadı (Grup A için 10 (\%10) ve Grup B için $34(\% 14)(p=0.251)$. İNM grubunda kalıcı RLN paralizi saptanmazken, direkt görsel teknikte istatistiksel olarak anlamlı fark oluşturan kalıcı RLN paralizi 10 hastada $(\% 4,3)$ tespit edildi $(\mathrm{p}=0,035)$.

Sonuç: IONM kullanımı, direkt görsel teknikle karşılaştırıldığında geçici paralizi oranlarında fark olmasa da kalıcı RLN paralizi oranını azaltmada faydalı olabilir.

Anahtar Kelimeler: Tiroidektomi, Rekürren laringeal, Sinir monitorizasyonu
${ }^{1}$ General Surgery Clinic, Haseki Teaching and Research Hospital, University of Health Sciences, Istanbul, Turkey

${ }^{2}$ General Surgery Clinic, Ministry of Health Lutfiye Nuri Burat State Hospital, Istanbul, Turkey

${ }^{3}$ Otorhinolaryngology Clinic, Ministry of Health Lutfiye Nuri Burat State Hospital, Istanbul, Turkey Ethics committe approval: The study was approved Etik Kurul: Calıșma lokal etik kurul tarafindan onaylanmıştır (10.08.2016/366).

Conflict of Interest: No conflict of interest was declared by the authors.

Çıkar Çatıșması: Yazarlar çıkar çatıșması bildirmemişlerdir.

Financial Disclosure: The authors declared that this case has received no financial support. Finansal Destek: Yazarlar bu olgu için finansal destek almadıklarını beyan etmişlerdir.

Geliș Tarihi / Received: 25.01.2018

Kabul Tarihi / Accepted: 28.02.2018

Yayın Tarihi / Published: 02.03.2018

Sorumlu yazar / Corresponding author Ahmet Kocakuşak

Adres/Address: Sağlık Bilimleri Üniversitesi, Haseki Eğitim ve Araştırma Hastanesi, Genel Cerrahi Kliniği, İstanbul, Türkiye

Tel: +905324484805

e-posta: ahmetkocakusak@yahoo.com

Copyright $($ C ACEM 


\section{Introduction}

Thyroidectomy is the most common intervention of head and neck surgery. The paralysis of recurrent laryngeal nerve (RLN) is one grave complication of the thyroid surgery which impairs the quality of life. The average incidences of permanent and temporary RLN palsies after thyroid operations are high (2.3\% and $9.8 \%$, respectively) [1]. To keep the rate of nerve damage to the lowest, surgical exposure and anatomic identification of the nerve during the surgery has been shown to be the best way.

No other cancer of any organ can match the increase in the rate of thyroid cancer in the recent years. For example, in South Korea the rate of thyroid cancer has increased 15 times even though the mortality remained the same [2]. The increase in the thyroid cancer has made it a problem of the developed countries. In the recent 20 years, the developed countries have reported 15 fold increase in the cancer of the thyroid gland. Cancers which probably would not have been symptomatic have become detectable because of the advances in the screening programs and the wider use of ultrasound. This has inevitably led to the rise in thyroidectomies.

Surgical exposure and anatomic identification of the RLN during thyroid operations has been shown to provide the best way of keeping the incidence of nerve injury to a minimum [3]. However, even experienced surgeons may harm the nerve due to variability of nerve anatomy and difficulties in nerve identification that may occur under challenging conditions [4].

Intraoperative nerve monitoring (IONM) during thyroid surgery has gained universal acceptance as an adjunct, not only for localizing and identifying the RLN but also as a way to predict vocal cord function and clarify the mechanisms of RLN injury. Neuro-monitoring is a tool that helps to visually identify the RLN and predicts postoperative nerve function, which is a great advantage over visualization alone; this technique could help prevent bilateral palsy [5]. Despite its increasing use, IONM is still considered as an adjunctive tool during thyroid surgery, taking a secondary role behind the gold standard of direct RLN visualization. The RLN paralysis is also a concern for surgeons in lawsuits for malpractice, even though it has a low rate [6].

The objective of the present retrospective study is to evaluate the outcome of thyroidectomies with nerve monitoring versus those in which nerve detection is made visually, and compare the results to define advantages and disadvantages of both procedures, with or without nerve monitoring.

\section{Material and methods}

The study plan was evaluated and approved by our institutional ethics committee of our teaching and research hospital. Approval of the local ethic committee was obtained. All procedures were in accordance with the Helsinki Declaration of 1964 and later versions. All patients have already been informed and written consent was obtained from all patients before the surgery for years indicating that their data could have been used in scientific research in the future, since the present study was a retrospective study on patients who underwent thyroidectomy using either intraoperative laryngeal nerve monitoring or using the conventional method with direct visual inspection in the general surgery departments of Lutfiye Nuri Burat State Hospital ve Haseki Training and Research Hospital between January 2015 and January 2017.

Patients younger than 18 years of age or with a previous thyroid or laryngeal operation (vocal polyp, nodule or larynx cancer) or who had a cerebrovascular disease history or who underwent subtotal or unilateral thyroidectomy were excluded from the study. The patients underwent laryngeal examination prior to the surgery in order to confirm the presence of intact vocal cord mobility and laryngeal configuration and for any other vocal fold lesions that might impact the outcome. Patients who underwent bilateral total thyroidectomy for benign goiter as well as thyroid cancer, diagnosed with a fine needle aspiration, between 18 and 80 years of age were included in the study.

The patients' age, medical history and details of the surgery were obtained from the patients' medical files. The operations were performed by the same surgeons who were experienced in the field and by the surgery residents of at least in the fourth years of their surgical training of the 5 years under the direction and supervision of the previously explained surgeons who also assisted the operation.

The patients were grouped into two: Thyroidectomy operations using IONM (Group A) and using direct visual inspection technique (Group B). The patients in Group A were intubated without administration of neuromuscular blocking agents. Endotracheal-based monitoring system (Medtronic NIM, Jacksonville, FL, USA) was used to record electromyographic activity of the thyroarytenoid muscles during the operation. Two electromyography (EMG) recordings were obtained from the both recurrent laryngeal nerves. The first one was taken when the nerves were detected and identified. Another EMG recording was obtained after the thyroidectomy was completed and complete homeostasis was achieved. The age, weight, height, preoperative diagnosis, American Society of Anesthesiologists (ASA) score, specimen size, pathology report, operation time, length of the hospitalization period, preoperative and postoperative calcium levels, complications, nerve conduction velocities and electromyographic activity levels were recorded for comparison. The operation time is defined as starting from skin incision to closure.

The larynx and vocal cord examinations were performed for all patients both before the surgery and in the early postoperative period. If dysphonia or vocal cord injury were encountered, follow-up examinations with indirect laryngoscopy were performed on the 3rd and 9th months. If the dysfunction and clinical dysphonia lasted more than 12 months in the postoperative period, the case was considered as facing "persistent nerve palsy".

Statistically, the data was analyzed with SPSS 15.0 for Windows. The descriptive statistics were given as mean \pm standard deviation, with minimum and maximum for quantitative variables, and as percentages for categorical variables. When quantitative variables had normal distribution pattern, Student t Test was employed for 2 independent samples and One Way Analysis of Variance (ANOVA). If the data was non-normally distributed, Mann Whitney U test was used for two independent samples and Kruskal Wallis analysis for more than two independent samples. The subgroup analysis for the nonparametric group was carried out with Mann Whitney U test. The rates were compared with chi-square analysis. Monte Carlo simulation was applied when necessary. Results were considered statistically significant when p value was less than 0.05 .

\section{Results}

As a whole, the mean age was $46.4 \pm 12.9$ years. Three hundred thirty two patients, of which $52(15.7 \%)$ were males and $280(84.3 \%)$ were females, had been included. While 100 (87 males, 13 females) were operated with IONM (Group A), the remaining 232 (193 males, 39 females) were operated without IONM (Group B). Average operation time was 90.7 \pm 25.7 (45180) minutes. Two hundred and thirty five (70.8\%) operations were bilateral, and 97 (29.2\%) operations were unilateral.

The study group had no operative and postoperative mortality. There were $10(3 \%)$ unilateral vocal cord paralysis at 
9th month and there was no persistent hypocalcemia. Ten patients $(3 \%)$ suffered non-life threatening hematomas, and 36 (10.6\%) patients had transient hypocalcemia. The preoperative mean calcium level was $8.6 \pm 0.5 \mathrm{mg} / \mathrm{dL}$ when compared to the postoperative level which was $8.3 \pm 0.9 \mathrm{mg} / \mathrm{dL}$ (Table 1). The operation duration in Group A was shorter than Group B as $76.9 \pm 12.0$ minutes vs $97.7 \pm 27.6$ minutes, respectively (Table 2 ).

Table 1: Demographic and clinical features of the patients $(n=332)$.

\begin{tabular}{|c|c|c|}
\hline \multicolumn{2}{|l|}{ Parameter } & \\
\hline \multicolumn{2}{|l|}{ Age $(\text { year })^{\mu}$} & $46.4 \pm 12.9$ \\
\hline \multicolumn{2}{|l|}{ Operation time $(\min )^{\mu}$} & $90.7 \pm 25.7$ \\
\hline \multicolumn{2}{|l|}{ Preoperative calcium $(\mathrm{mg} / \mathrm{dL})^{\mu}$} & $8.6 \pm 0.5$ \\
\hline \multicolumn{2}{|l|}{ Postoperative calcium $(\mathrm{mg} / \mathrm{dL})^{\mu}$} & $8.3 \pm 0.9$ \\
\hline \multirow[t]{2}{*}{ Gender $^{\beta}$} & Male & $52(15.7)$ \\
\hline & Female & $280(84.3)$ \\
\hline \multirow[t]{2}{*}{ Usage of IONM $^{\beta}$} & IONM & $100(30.1)$ \\
\hline & Non-IONM & $232(69.9)$ \\
\hline \multirow[t]{2}{*}{ Side $^{\beta}$} & Bilateral & $235(70.8)$ \\
\hline & Unilateral & $97(29.2)$ \\
\hline \multirow[t]{3}{*}{ Vocal cord failure $^{\beta}$} & 24 hours & $44(13.3)$ \\
\hline & 3 months & $18(5.4)$ \\
\hline & 9 months & $10(3.0)$ \\
\hline \multirow[t]{3}{*}{ Complications $^{\beta}$} & No complication & $286(86.1)$ \\
\hline & Hematoma & $10(3.0)$ \\
\hline & Hypocalcemia & $36(10.8)$ \\
\hline Co-morbidities ${ }^{\beta}$ & & $6(1.8)$ \\
\hline
\end{tabular}

${ }^{\mu}$ : mean \pm standard deviation, ${ }^{\beta}: \mathrm{n}(\%)$, IONM: Intraoperative nerve monitoring

Table 2: Comparison of the groups

\begin{tabular}{|c|c|c|c|c|}
\hline \multirow[t]{2}{*}{ Parameter } & & $\begin{array}{c}\text { With IONM } \\
\text { (Group A) }\end{array}$ & $\begin{array}{c}\text { Without IONM } \\
\text { (Group B) }\end{array}$ & \multirow[b]{2}{*}{$\mathrm{p}$} \\
\hline & & $\mathrm{N}$ & $\mathrm{N}$ & \\
\hline $\begin{array}{l}\text { Operation time }{ }^{\mu} \\
\text { (minutes) }\end{array}$ & & $76.9 \pm 12.0$ & $96.7 \pm 27.6$ & 0.001 \\
\hline $\begin{array}{l}\text { Preoperative } \\
\text { calcium levels } \\
(\mathrm{mg} / \mathrm{dl})^{\mu}\end{array}$ & & $8.6 \pm 0.5$ & $8.6 \pm 0.5$ & 0.407 \\
\hline $\begin{array}{l}\text { Postoperative } \\
\text { calcium levels } \\
(\mathrm{mg} / \mathrm{dl})^{\mu}\end{array}$ & & $8.4 \pm 0.7$ & $8.3 \pm 1.0$ & 0.743 \\
\hline Gender $^{\beta}$ & Male & $13(13)$ & $39(16.8)$ & 0.381 \\
\hline & Female & $87(87)$ & $193(83.2)$ & \\
\hline Side $^{\beta}$ & Bilateral & $78(78)$ & $157(67.7)$ & 0.058 \\
\hline & Unilateral & $22(22)$ & $75(32.3)$ & \\
\hline Vocal cord failure $^{\beta}$ & 24 hours & $10(10)$ & $34(14.7)$ & 0.251 \\
\hline & 3rd month & $0(0)$ & $18(7.8)$ & 0.004 \\
\hline & 9th month & $0(0)$ & $10(4.3)$ & 0.035 \\
\hline Complications $^{\beta}$ & No complication & $88(88)$ & $198(85.3)$ & 0.777 \\
\hline & Hematoma & $3(3)$ & $7(3.0)$ & \\
\hline & Hypocalcemia & $9(9)$ & $27(11.6)$ & \\
\hline Co-morbidity ${ }^{\beta}$ & & $6(6)$ & $0(0)$ & 0.001 \\
\hline
\end{tabular}

${ }^{\mu}$ : mean \pm standard deviation, ${ }^{\beta}: \mathrm{n}(\%)$, IONM: Intraoperative nerve monitoring

When we evaluated the patients according to the employment of IONM as a whole, there was significant difference between the overall operation duration between the groups. There was no difference among preoperative and postoperative calcium levels $(\mathrm{p}=0.407)$. There was also no difference between gender and the laterality of the operation between the two groups, either $(\mathrm{p}=0.381)$. Considering the postoperative complications, each group had a rate of $3 \%$ for development of hematomas and there was no difference between the incidence of hypocalcemia ( $9 \%$ vs $11.6 \%, \mathrm{p}=0.777$ ). However, there were $10(10 \%)$ and $34(14.7 \%)$ cases of vocal cord disturbances in Group A and Group B, respectively, in the early postoperative vocal cord examination within 24 hours after the operation $(\mathrm{p}=0.251)$.

On the vocal cord examination in the 3rd month, there was no persistent laryngeal nerve damage in Group A, but there were $18(7.8 \%)$ patients with persistent laryngeal nerve damage in Group B ( $\mathrm{p}=0.004)$. There were $10(4.3 \%)$ patients who still had laryngeal nerve damage in Group $B$ in the 9th month contrary to the absence of persistent laryngeal nerve damage in Group A ( $\mathrm{p}=0.035)$.

\section{Discussion}

Since we are on the process of adopting IONM in our surgery departments, the present study was conducted by the cooperation of two surgical departments. Although there was no significant difference between the groups in the early postoperative nerve palsy rates $(10 \%$ and $14.7 \%)$, in the followup, there were more persistent nerve palsy cases in the patients without IONM $(0 \%$ and $4.3 \%)$.

The most important complications of thyroidectomy are recurrent nerve palsy and hypoparathyroidism among other potential surgical complications like hematomas. The nerve palsy may lead to voice alterations as well as aspiration and related health consequences.

The incidence of recurrent nerve palsy has been reported between less than $1 \%$ and up to $20 \%$ [7]. Even in experienced centers, the authors have reported rates of injury to the recurrent nerve causing persistent palsy around 1-2\% [8, 9].

In a large multicenter study evaluating more than 27 000 nerves at risk for surgical trauma, it has been argued that the outstanding factor in the success of thyroid surgery is the surgeon's individual performance; the meticulous dissection, identification and preservation of the recurrent nerves [10]. In another study, which the surgeons were stratified according to their experiences, it has been shown that surgeons with experience more than a hundred thyroidectomies had lowest complication rates and shorter hospital stay [11].

In a prospective study about the thyroidectomies performed by experienced surgeons, $8 \%$ of the cases presented symptoms of nerve injury at early evaluation but only one in 301 patients had persistent symptoms in the long term follow up [12].

In addition to the surgeons experience, there are several factors which put the nerve at high risk, the underlying disease (substernal goiter, malignancy, Graves disease), as well as the extent of resection. Lahey et al [13] reported that careful dissection of the recurrent nerve decreased the number of injured recurrent laryngeal nerves hence advocating the dissection of the nerve almost in every case. However this may not be so easy under several circumstances such as cancer excision, anatomic distortion of large tumors, anatomic anomalies, history of radiation and inflammation [7].

Nerve monitoring has been introduced in order to help the surgeons to identify the recurrent nerve intraoperatively [14]. There are several arguments in favor of neuro-monitoring, the ability of the surgeon to correctly identify the nerve, to maintain reliable prediction about its functional integrity of the nerve before the end of the operations to cancel bilateral surgery, to aid the surgeon for guidance in difficult situations like cancer or recurrent operations [15].

Neuronal integrity method (NIM) requires a particular endotracheal tube with electrodes for the vocal cord embedded into the wall of the tube. NIM is one of the most common used methods of nerve monitoring [16]. However, it is not the surgeons' skills only; the endotracheal tube with the electrodes needs to be placed accurately by the anesthesiologist to be in contact with the vocal cords $[17,18]$.

Many attempts have been made in recent years to investigate the role of IONM as an essential tool for RLN identification, but there has been conflicting reports, not yet enough to establish the role of NIM as a confirmed tool to aid the surgeon in thyroidectomies.

One argument against the efficiency of NIM in several papers is that it does not reduce the operation time [1]. For example, Stevens et al [19] reported a longer mean operation time of 180 minutes of the IONM group vs 130.5 minutes for the visual nerve inspection only group. On the contrary, Sari et al. 
[7] reported a shorter operation time as $65.4 \pm 31$ minutes for the IONM group than $79.1 \pm 30$ minutes for the visualization group. Chan et al [20] reported $119 \pm 51$ minutes vs $116 \pm 37$ minutes, hence very close figures for the IONM and visual inspection groups, respectively. Dionigi et al [21] reported closer mean operation time results as 97.6 vs 95.0 minutes for IONM and without IONM groups, respectively. In our evaluation of the patients according to the employment of IONM, there was a significant difference between the overall operation duration time between the groups. The length of operation in IONM group was shorter than the non-IONM group as $76.9 \pm 12.0$ vs $97.7 \pm 7.6$ minutes. Thus, our study clearly confirms that in a setting where residents are trained and IONM has become somewhat habitual, the operation period might actually shorten because of spending less time for a meticulous and careful dissection of the nerve. This may be the result of saving extra time taken to assure the safety of the operation in a teaching hospital; however, any tool cannot be a substitute for the guiding hand of an experienced instructor.

In regard to RLN, several studies may be mentioned favoring or being against for the employment of IONM. In one study, the authors retrospectively compared 656 cases of thyroid cancer patients who underwent bilateral thyroidectomy with IONM and by visual detection. In this study, it has been shown that differences were not statistically significant [22].

In a famous large prospective German study, the authors found out that the use of IONM significantly decreased the early RLN palsy rates from $4.9 \%$ to $3.3 \%$, and they reported that IONM was beneficial in high-risk procedures such as recurrent goiter, thyroid carcinoma and extended resections [16].

When the debate around the subject was becoming more complicated, several meta-analyses have been made and metaanalyses of those overlapping meta-analyses have been performed. In one meta-analysis of 9,203 patients and 17,203 nerves at risk, incidence of overall, transient, and persistent RLN palsy in IONM group were $3.15 \%, 1.82 \%$, and $0.67 \%$, respectively, whereas for the visual detection group, they were $4.37 \%, 2.58 \%$, and $1.07 \%$, respectively. The presented data showed benefits of reducing RLN palsy rate by using IONM, but without statistical significance for persistent RLN palsy rate. In addition, it was proposed that patients with thyroid cancer who undergo total thyroidectomy using IONM, the outcome may improved by reducing amount of residual thyroid tissue [23].

Wong et al [24] reviewed 10 studies for high risk thyroidectomies namely re-operation, thyroidectomy for malignancy, thyrotoxicosis or retrosternal goiter and found that IONM had significantly lower rate of overall (4.5\% vs. $2.5 \%)$ and temporary (3.9\% vs. $2.4 \%$ ) RLN palsy in overall high-risk thyroidectomies than they are for the visual investigation group. They concluded that selective use of IONM during high-risk thyroidectomy decreased the rate of overall RLN palsy. IONM should be used for re-operative thyroidectomy and operations for cancer [24].

Another meta analysis based on five randomized clinical trials and 12 comparative trials evaluating 36,487 at-risk nerves were included. Statistically significant differences in terms of total recurrent laryngeal nerve palsy as $3.37 \%$ with intra-operative nerve monitoring and $3.76 \%$ without IONM and transient recurrent laryngeal nerve palsy as $2.56 \%$ with IONM and $2.71 \%$ without IONM were identified. The persistent incidence of recurrent laryngeal nerve palsy was $0.78 \%$ for IONM and $0.96 \%$ for visual nerve identification alone. Based on this meta-analysis, statistically significant differences were determined in terms of the incidences of total and transient recurrent laryngeal nerve palsy after using IONM during thyroidectomy. However, no statistically significant differences were identified regarding the incidence of persistent recurrent laryngeal nerve palsy between the groups [25].

Pisanu et al [26] found that there was no statistically significant difference in the incidence of RLN palsy when using IONM during thyroidectomy. The rates of overall RLN palsy per nerve at risk were $3.47 \%$ using IONM and $3.67 \%$ without using IONM. The rates of transient RLN palsy per nerve at risk were $2.62 \%$ and $2.72 \%$ in the groups with and without IONM, respectively. The rates of permanent RLN palsy per nerve at risk were $0.79 \%$ in patients with IONM compared to $0.92 \%$ without IONM [26].

Although there was no difference between the groups with and without IONM in the present study in the early postoperative nerve palsy rates (10\% and $14.7 \%$, respectively), in the follow-up, there were more persistent nerve palsy cases in Group B (non-IONM group). According to these findings, it may be concluded that regeneration of some damaged nerves with time is easier due to the less traumatic effect of IONM.

Sanabria et al [27] could not find a statistically significant decrease in the risk of temporary or definitive RLN injury. The proponents of routine nerve monitoring claim that its use can still be justified for bilateral surgery stating that contralateral lobe resection must be avoided after loss of signal in the first lobe to avoid the risk of bilateral damage and tracheostomy [27].

Supplementary role of IONM is supported by the recommendations by the German Association of Endocrine Surgeons' guidelines for thyroid disease and supported by the International Intraoperative Monitoring Study Group's international standards guideline statement [28].

In conclusion, it may be proposed that NIM or IONM may be helpful especially in departments where thyroidectomy is performed with lower volumes. Since the high rate of endemic goiter in Turkey mandates and forces the performance of thyroidectomies even in smaller departments with lower volumes, thus IONM may be a useful tool to improve the quality of the surgery by using neuro-monitoring. In regard to improvement of all patients with transient nerve palsies using IONM, regeneration of some damaged nerves with time may be easier.

\section{References}

1. Henry BM, Graves MJ, Vikse J, Sanna B, Pękala PA, Walocha JA, et al. The current state of intermittent intraoperative neural monitoring for prevention of recurrent laryngeal nerve injury during thyroidectomy: a PRISMA-compliant systematic review of overlapping meta-analyses. Langenbecks Arch Surg. 2017;402:663-73.

2. Ahn HS, Kim HJ, Welch HG. Korea's thyroid-cancer epidemic:screening and overdiagnosis. N Engl J Med. 2014;371:1765-7.

3. Lo CY, Kwok KF, Yuen PW. A prospective evaluation of recurrent laryngeal nerve paralysis during thyroidectomy. Arch Surg. 2000;135:204-7.

4. Dionigi G, Chiang FY, Rausei S, Wu CW, Boni L, Lee KW, et al Surgical anatomy and neurophysiology of the vagus nerve (VN) for standardised intraoperative neuromonitoring (IONM) of the inferior laryngeal nerve (ILN) during thyroidectomy. Langenbecks Arch Surg. 2010;395:893-9.

5. Chiang FY, Lee KW, Chen HC, Chen HY, Lu IC, Kuo WR, et al. Standardization of intraoperative neuromonitoring of recurrent laryngeal nerve in thyroid operation. World J Surg. 2010;34:223-9.

6. Duclos A, Lifante JC, Ducarroz S, Soardo P, Colin C, Peix JL Influence of intraoperative neuromonitoring on surgeons' technique during thyroidectomy. World J Surg. 2011;35:773-8.

7. Sarı S, Erbil Y, Sümer A, Agcaoglu O, Bayraktar A, Issever H, et al Evaluation of recurrent laryngeal nerve monitoring in thyroid surgery. Int J Surg. 2010;8:474-8

8. Filho JG, Kowalski LP. Surgical complications after thyroid surgery performed in a cancer hospital. Otolaryngol Head Neck Surg. 2005;132:490-4. 
9. Cirocchi R, Boselli C, Guarino S, Sanguinetti A, Trastulli S, Desiderio J, et al. Total thyroidectomy with ultrasonic dissector for cancer: multicentric experience. World J Surg Oncol. 2012;10:70.

10. Hermann M, Alk G, Roka R, Glaser K, Freissmuth M. Laryngeal recurrent nerve injury in surgery for benign thyroid diseases: effect of nerve dissection and impact of individual surgeon in more than 27,000 nerves at risk. Ann Surg. 2002;235:261-8.

11. Sosa JA, Bowman HM, Tielsch JM, Powe NR, Gordon TA, Udelsman R. The importance of surgeon experience for clinical and economic outcomes from thyroidectomy. Ann Surg. 1998;228:320-30.

12. Rios-Zambudio A, Rodriguez J, Riquelme J, Soria T, Canteras M, Parrilla P. Prospective study of postoperative complications after total thyroidectomy for multinodular goiters by surgeons with experience in endocrine surgery. Ann Surg. 2004;240:18-25.

13. Lahey RF. Routine dissection and demonstration of the recurrent laryngeal nerve in subtotal thyroidectomy. Surg Gynecol Obstet. 1938;66:775-7.

14. Chan WF, Lo CY. Pitfalls of intraoperative neuromonitoring for predicting postoperative recurrent laryngeal nerve function during thyroidectomy. World J Surg. 2006;30:806-12.

15. Hermann M, Hellebart C, Freissmuth M. Neuromonitoring in thyroid surgery: prospective evaluation of intraoperative electrophysiological responses for the prediction of recurrent laryngeal nerve injury. Ann Surg. 2004;240:9-17.

16. Thomusch O, Sekulla C, Machens A, Neumann HJ, Timmermann W, Dralle $\mathrm{H}$. Validity of intra-operative neuromonitoring signals in thyroid surgery. Langenbecks Arch Surg. 2004;389:499-503.

17. Angelos P. Recurrent laryngeal nerve monitoring: state of the art, ethical and legal issues. Surg Clin North Am. 2009;89:1157-69.

18. Dralle H, Sekulla C, Haerting J, Timmermann W, Neumann HJ, Kruse $\mathrm{E}$, et al. Risk factors of paralysis and functional outcome after recurrent laryngeal nerve monitoring in thyroid surgery. Surgery. 2004;136:131022.

19. Stevens K, Stojadinovic A, Helou LB, Solomon NP, Howard RS, Shriver $\mathrm{CD}$, et al. The impact of recurrent laryngeal neuromonitoring on multi-dimensional voice outcomes following thyroid surgery. J Surgical Oncol. 2012;105:4-9.

20. Chan WF, Lang BHH, Lo CY. The role of intraoperative neuromonitoring of recurrent laryngeal nerve during thyroidectomy: a comparative study on 1000 nerves at risk. Surgery. 2006;140:866-73.

21. Dionigi G, Boni L, Rovera F, Bacuzzi A, Dionigi R. Neuromonitoring and video-assisted thyroidectomy: a prospective, randomized casecontrol evaluation. Surg Endosc. 2009;23:996-1003.

22. Calo PG, Medas F, Erdas E, Pittau MR, Demontis R, Pisano G, et al. Role of intraoperative neuromonitoring of recurrent laryngeal nerves in the outcomes of surgery for thyroid cancer. Int J Surg. 2014;12:S213-7.

23. Yang S, Zhou L, Lu Z, Ma B, Ji Q, Wang Y. Systematic review with meta-analysis of intraoperative neuromonitoring during thyroidectomy. Int J Surg. 2017;39:104-13.

24. Wong KP, Mak KL, Wong CKH, Lang BHH. Systematic review and meta-analysis on intra-operative neuro-monitoring in high-risk thyroidectomy. Int J Surg. 2017;38:21-30.

25.Zheng S, Xu Z, Wei Y, Zeng M, He J. Effect of intraoperative neuromonitoring on recurrent laryngeal nerve palsy rates after thyroid surgery - a meta-analysis. J Formos Med Assoc. 2013;112:463-72.

26. Pisanu A, Porceddu G, Podda M, Cois A, Uccheddu A. Systematic review with meta-analysis of studies comparing intraoperative neuromonitoring of recurrent laryngeal nerves versus visualization alone during thyroidectomy. J Surg Res. 2014;188:152-61.

27. Sanabria A, Ramirez A, Kowalski LP, Silver CE, Shaha AR, Owen RP, et al. Neuromonitoring in thyroidectomy: a meta-analysis of effectiveness from randomized controlled trials. Eur Arch Otorhinolaryngol. 2013;270:2175-89.

28. Musholt TJ, Clerici T, Dralle H, Frilling A, Goretzki PE, Hermann MM. German Association of Endocrine Surgeons practice guidelines for the surgical treatment of benign thyroid disease. Langenbecks Arch Surg. 2011;396:639-49. 